\title{
Research and Practice of Mobile Learning Model under the Integration of Open Education and Vocational Education
}

\author{
Guangjun Ma, Bingbing Wu*, Guiqiang Lu, Haibo Zhang \\ Liaoning Equipment Manufacturing Professional Technology College \\ Shenyang, China \\ Eail:405950341@qq.com
}

\begin{abstract}
Under the guidance of the concept of lifelong education, the integration of open education and vocational education is accelerating. Two different types of education are integrated in professional settings, the teaching modes are integrated and the curriculum resources are shared and shared. With the rapid development of mobile Internet technology in recent years, mobile learning has become one of the research hotspots in the field of open education and higher vocational education. This paper expounds the research status of mobile learning models at home and abroad, and applies the " $1+\mathrm{N}$ " mobile learning model in the teaching of open education and higher vocational education, and has achieved good results.
\end{abstract}

Keywords-Open Education; Higher Vocational Education; Mobile Learning; Mode; $1+N$

With the widespread application of computer technology, network technology, and mobile communication technology, mobile learning has attracted more and more attention. Mobile learning is a new teaching model of open education and higher vocational education. It is a new type of learning method that uses wireless mobile communication network technology and wireless mobile communication equipment to obtain educational information, educational resources and education services. It has the characteristics of learning convenience, teaching individuation, openness, interactive richness, situational relevance and so on.

\section{Status Quo OF Research ON MobILE LEARNING}

At present, scholars at home and abroad have conducted in-depth studies on mobile learning. For example, the University of Kingston, UK conducted an experiment to evaluate the effectiveness of short message service in education and teaching. Based on experimental needs, they developed a short message service system that can be used to send learners information such as course schedules, exam schedules, and test scores. Experiments have shown that learners are more inclined to obtain SMS-based information in some contexts [1-3]. At the University of Helsinki, Finland, short message services were used for teacher training. The preliminary test results were satisfactory. At the same time, they plan to use multimedia messaging (MMS) technology in education and teaching in the next study to achieve the generation and transmission of digital images through mobile devices [4-7]. Based on the research objectives of the M-learning program in the United Kingdom, Ultralab developed and established a WAP education site that supports mobile learning by analyzing the learning characteristics of young people aged 16 to 24 in Europe. The researchers focused on selecting students who can live and work close to learners. More fashionable and popular themes as learning content [8-9]. Due to the key role WAP education sites play in mobile learning, many universities have established their own WAP education sites in the past few years. Typical examples are: Griffith University and Minnesota State University, Canada, NAIT and so on.

\section{THE PROBLEMS IN THE StUdy OF MOBILE LEARNING MODE}

\section{A. The development of mobile networks}

Mobile communication technology from $3 \mathrm{G}$ to $4 \mathrm{G}$, the transmission rate of more than 100 million, which provides a guarantee for the transmission of mobile learning teaching files, with the application of cloud computing technology in mobile communication devices, learners can perform data in the terminal device , material interaction and experience.

\section{B. Development of mobile communication equipment}

Mobile communication equipment is the main carrier in mobile learning. With the rapid development of a new generation of information technology, the functional terminals in the form of mobile phones, tablet computers, etc. are changing with each passing day, which improves the learners' experience and interest, and also makes the terminal learning form more colorful.

\section{Problems of mobile terminal learning software development}

We have developed mobile learning software that is easy to operate, rich in content, and highly interactive. It is installed on the learning platform. The learning columns are clear and concise, and task-driven micro lessons, videos, and interactions are developed animation. 


\section{THE APPLICATION OF "1+N" MOBILE LEARNING MODE}

A. " $1+N$ " mobile learning mode

" 1 " in the " $1+\mathrm{N} "$ mobile learning mode means learner-centered and has one or more mobile learning terminals; "N" refers to any time, any place, any learning mode, learning, practice, and Recreation activities [10-11].

It can be seen that during the entire learning process, students are the main body of learning, and teachers only play a role in helping to guide and promote them.

\section{B. Several application forms of " $1+N$ " mobile learning mode}

The realization of mobile learning is based on the use of different communication protocols: mobile learning based on WeChat, mobile learning based on multimedia MMS, mobile learning based on connection browsing, and mobile learning modes based on on-demand and offline.

\section{1) Wechat-based mobile learning mode}

Wechat's cross-platform features are better. It doesn't take into account what kind of system the user uses. The user's training cost is low, timeliness is high, it is easy to spread, and the development cost is low; but the disadvantages are also obvious, such as unable to learn offline, open any one All online courses require online and security is weak and cannot be compared with APP. Furthermore, due to the limited interface provided by WeChat, learning records can not be fully tracked, individualized requirements are also more difficult to achieve, and management background has limitations. WeChat is a universal mobile learning approach. As a means of communication and communication, short message service has been widely used.

\section{2) APP-based mobile learning model}

The advantage of APP is that it is easy to expand; it can meet the individual needs of learners, and has high security. It can learn offline. For example, some video courses can be cached in a WIFI environment. Users can learn without a network environment, but less. The consumption of user's traffic, management background is powerful, and it is conducive to the construction of training brands. The disadvantage is higher development costs and higher user training costs than WeChat.

\section{3) Mobile learning mode based on multimedia MMS}

The MMS message may contain a combination of one or more media formats among sounds, pictures, and video clips. Through the multimedia short message service provided by 4G, the learner can send the short message to the teaching server through the terminal. After the teaching server analyzes and processes the received data, it can automatically reply the information to the learner in the form of a short message. Of course, learners can also discuss and solve problems through the form of short messages.

\section{4) Video on demand based mobile learning mode}

With the help of the network bandwidth provided by 4G technology, learners can obtain high network transmission bandwidth no matter they are indoors, outdoors or in the process of moving, and they can easily realize the leap from text-on-demand, picture-on-demand to audio-video on-demand [4]. Based on this business, we can develop some courses that are suitable for learners to watch and simulate learning through the mobile phone software development kit, and make full use of 4G's bandwidth advantage to provide mobile learning services. Compared with previous TV education and online education programs based on cable networks, it has greater flexibility and can be used to access the Internet anytime, anywhere, and is free to learn. It is more suitable for modern fast-paced learning groups [12-16].

\section{Practice of Mobile Learning Mode in Open EDUCATION TEACHING}

In 2013, our university undertook the task entrusted by the National Open University, "Distance Education Supporting Vocational Education Research, which is a study of mobile learning model”. Our school conducted a questionnaire survey of open education students and higher vocational students. The results of the survey are shown in Table 1 to Table 4 . The results show that students in open education and higher vocational education fully possess the conditions for mobile learning. For the use of WeChat groups, higher vocational students are higher than open students, and the desire to use mobile learning is the same [17-18].

TABLE I. STATISTICS OF OPEN EDUCATION STUDENT S' ACCEPTANCE OF MOBILE LEARNING

\begin{tabular}{|c|c|c|c|}
\hline $\begin{array}{l}\text { Grades of } \\
\text { students } \\
\text { surveyed }\end{array}$ & $\begin{array}{l}\text { Students } \\
\text { have mobile } \\
\text { device } \\
\text { status \% }\end{array}$ & $\begin{array}{l}\text { Use WeChat } \\
\text { group } \\
\text { condition }\end{array}$ & $\begin{array}{c}\text { Use mobile } \\
\text { learning wish }\end{array}$ \\
\hline Spring of 2013 & $96.2 \%$ & $87 \%$ & $100 \%$ \\
\hline Fall of 2013 & $99 \%$ & $98.2 \%$ & $100 \%$ \\
\hline
\end{tabular}

TABLE II. ST ATIST ICSON THE SELECTION OF LEARNING RESOURCES BY OPEN EDUCATION STUDENTS

\begin{tabular}{|c|c|c|c|}
\hline $\begin{array}{c}\text { Student's grade } \\
\text { of survey }\end{array}$ & Text class & $\begin{array}{c}\text { Animation, } \\
\text { video }\end{array}$ & Text, audio \\
\hline September 2013 & $30.6 \%$ & $34 \%$ & $35.4 \%$ \\
\hline December 2013 & $32 \%$ & $37 \%$ & $31 \%$ \\
\hline
\end{tabular}

TABLE III. ST ATISTICS OF RECOGNITION OF MOBILE LEARNING BY STUDENTS IN HIGHER VOCATIONAL EDUCATION

\begin{tabular}{|c|c|c|c|}
\hline $\begin{array}{c}\text { Grades of } \\
\text { students } \\
\text { surveyed }\end{array}$ & $\begin{array}{c}\text { Students have } \\
\text { mobile device } \\
\text { status \% }\end{array}$ & $\begin{array}{c}\text { Use WeChat } \\
\text { group } \\
\text { condition }\end{array}$ & $\begin{array}{c}\text { Use mobile } \\
\text { learning } \\
\text { wish }\end{array}$ \\
\hline March 2013 & $95.3 \%$ & $88.1 \%$ & $100 \%$ \\
\hline September 2013 & $98.5 \%$ & $99.5 \%$ & $100 \%$ \\
\hline
\end{tabular}

TABLE IV. STATISTICS ON SELECTION OF LEARNING RESOURCES BY HIGHER VOCATIONAL STUDENTS

\begin{tabular}{|c|c|c|c|}
\hline $\begin{array}{c}\text { Student's grade } \\
\text { of survey }\end{array}$ & Text class & $\begin{array}{c}\text { Animation } \\
\text {, video }\end{array}$ & Text, audio \\
\hline September 2013 & $29.5 \%$ & $36.2 \%$ & $34.3 \%$ \\
\hline December 2013 & $32 \%$ & $37 \%$ & $31 \%$ \\
\hline
\end{tabular}




\section{The Practice of Mobile Learning Mode in Higher Vocational TeAching-BASED INTERNShip PRACTICE}

\section{A. Problems existing in the process of internship for higher vocational students}

The integration of production and education, work-study integration is based on students as the mainstay, employment-oriented, the use of industry resources, the combination of classroom teaching and corporate practice teaching mode. In the process of internships for students, the complexity, authenticity, work experience and guidance of the environment and the development of teaching activities need to be improved and strengthened.

1) The practical teaching conditions are inconsistent with the company's job requirements

At present, the practical teaching conditions in most vocational colleges in China are constrained by the number of training equipment, the authenticity of the equipment, and the advanced nature, and cannot be connected with the skills required for actual positions or work processes. Therefore, it is difficult to It is a zero distance docking for students to graduate and employment.

\section{2) There is a serious shortage of high-quality dual-teacher} teachers.

The group structure and individual qualities of the teaching staff can not meet the teaching needs, especially the shortage of teachers with "dual qualifications", and the overall level of the "dual-qualification" teachers team construction is still not ideal, although some schools develop and introduce advanced levels through internal potential exploration. Professional titles, highly educated personnel, and teacher team construction have achieved certain results, but their structural contradictions are still very prominent. The teacher's own hands-on ability is not strong, and the ability-based principle of higher vocational education can hardly be effectively implemented.

3) Teaching content during the internship is difficult to implement effectively

More than half of the internships for students in higher vocational colleges are based. Our school adopts the " $2+1$ " model, which means studying in the university for two years and internships for companies in one year. We have made great efforts to study and discuss student learning and management issues during the internship. It is only possible for some companies and posts, and most of the teaching content is difficult to implement.

\section{B. The practice of mobile learning mode in the internship}

In response to the above three issues, first, teachers have been sent to the scene; second, the first-line engineering and technical personnel of the company have been hired as instructors to implement the dual-teacher system; and the third is based on the typical project of the intern company and the enterprise engineering technicians. Develop task-driven teaching resources. The network management system for the top post-employment students established by our university includes the Internet class, information release, information feedback, academic management, and teaching evaluation.

\section{SUMMARY}

At present, mobile learning at home and abroad is in the ascendant. Through mobile learning, the integration of open education and higher vocational education can be promoted, which can greatly improve learners' learning effects and promote the improvement of teaching quality. As a new way of learning, mobile learning will certainly play a catalytic role in creating a learning society and lifelong learning.

\section{REFERENCES}

[1] Shen Yang. Research on Micro-course Design Based on Mobile Learning in Vocational Education [J], Journal of Changchun Institute of Education, 2015(4), pp154-155.(In Chinese)

[2] Xue Jianqiang. Research on the Construction and Development of College English Mobile Learning Model [J], Experimental Technology and Management, 2014(3), pp95.(In Chinese)

[3] Gong Jing. Mobile Learning in Continuing Education in China [D], Hebei Normal University, 2017(8), pp113.(In Chinese)

[4] Hu Min. Student participation model and application research in online learning[D], Central China Normal University, 2015(8), pp113.(In Chinese)

[5] Wu Wenyan's e-learning training content design for new employees in the company [D], Shanghai Normal University, 2015 (8), pp113.(In Chinese)

[6] Zhang Hao, Yang Lingxia, Ding Caoxi. An analysis of the cultural background of the rise of micro-learning [J]. China Electrification Education, 2014, (2) 6, pp 15.(In Chinese)

[7] Yu Ling. Inquiry and analysis on the necessity of mobile learning based on smart phone in college English, contemporary education practice and teaching, 2015.(In Chinese)

[8] Wang Chongwen, Ren Xiang. A study of micro-learning model based on mobile smart phones, Journal of Yunnan Un iversity (Natural Science Edition) 2014 (1), pp135.(In Chinese)

[9] Zhang Kaixin. Design and research of mobile micro-learning activities based on smart phones, China Education Informatization 2015 (12), pp13.(In Chinese)

[10] Bao Hongfei. World Bank Loan Liaoning Vocational Education Reform Project [M], Northeastern University Press, June 2015.(In Chinese)

[11] Li Long. On the Design and Implementation of "Micro-learning" [J]. Audio-visual education research, 2014 (2), pp74-83.(In Chinese)

[12] Jiang Qiang, Zhao Wei, Wang Pengjiao. Research on mobile learning cognition of college students based on smart phone in the view of fragmented learning[J]. Modern Distance Education, 2014(1), pp37-42.(In Chinese)

[13] Wang Xiaogen, Deng Liejun. Research on mobile learning resource organization mode based on knowledge element [J], Electrification Education Research, 2017(1), pp90.(In Chinese)

[14] Huang Hao. Research and Practice of Mobile Learning Mode Based on Micro-course [J], Industrial and Information Education, 2016(5), pp16.(In Chinese)

[15] Wang Yuxi. Research on mobile learning mode based on WeChat platform[D], Yunnan Normal University, 2016(8), pp115.(In Chinese)

[16] Bi Xiaomei, School Improvement Research Based on Smart Learning Environment [D], Southwest University, 2015 (8), pp108.(In Chinese)

[17] IEEE International Workshop on Wireless and Mobile Technologies in Education(WMTE2001) [DB/OL]. http://lttf:ieee.org/wmte2002.

[18] The Mobilearn project consortium. Mobilearn project Public results [EB/OL]. http://www.mobilearn. org/re- sults/results.htm, 2007-1-10. 